\title{
PENGARUH PENAMBAHAN TELUR TERHADAP KADAR PROTEIN, SERAT, TINGKAT KEKENYALAN DAN PENERIMAAN MIE BASAH BEBAS GLUTEN BERBAHAN BAKU TEPUNG KOMPOSIT. (TEPUNG KOMPOSIT : TEPUNG MOCAF, TAPIOKA DAN MAIZENA)
}

\author{
Yustisia Risti, Arintina Rahayuni* \\ Program Studi Ilmu Gizi Fakultas Kedokteran Universitas Diponegoro \\ Jl.Dr.Sutomo No.18, Semarang, Telp (024) 8453708, Email : gizifk@undip.ac.id
}

\begin{abstract}
Background : People with Autism Spectrum Disorder (ASD) and celiac disease cannot accept gluten in their body. Noodles is one of staple foods that made from wheat. Wheat has high level of gluten, while noodle is the second staple foods after rice. One of the alternative gluten-free carbohydrate source is cassava. Cassava can be processed into mocaf and tapioca flour which physically similar with wheat flour and in the future those flour are expected to substitute wheat flour in noodle industry. Cassava has low protein level, based on it, this experimental research wants to find out the effect of egg addition to the level of protein to match the Indonesian National Standard (SNI) $8 \%$ also the level of fiber, elasticity degree and acceptance of gluten-free wet noodles made from composite flour (mocaf, tapioca and cornstarch flour).

Objective : Analyzing egg addition effect to the level of protein, fiber, elasticity degree and acceptance of glutenfree wet noodles made from composite flour.

Method : A randomized experimental design using one control and three variations of eggs addition (5 eggs, 6 eggs and 7 eggs). Laboratory test is required for analyzing the protein level, fiber level and the elasticity degree. Acceptance test are conducted with the hedonic test by 20 semi-trained panelists. Statistical analysis of protein level, fiber level and the elasticity degree was tested using ANOVA One Way CI 95\% to further test LSD (Least Significance Different). Statistical analysis to the acceptance degree was tested using Friedman CI 95\% with further Wilcoxon test.

Results : Addition of eggs affect the levels of protein, fiber and the elasticity degree of gluten-free wet noodles. Addition of eggs also affects the level of acceptance in terms of color and texture but does not affect the aroma and flavor. Best assessment results obtained on 5 eggs gluten-free wet noodles made from composite flour with a protein content of $7.66 \%, 0.84 \%$ fiber and elasticity degree $41.83 \mathrm{~mm} / \mathrm{g} / \mathrm{sec}$.

Conclusion : 5 eggs gluten-free wet noodle is the best noodle and acceptable by the panelists. This noodle protein intake accounted for $15.32 \%$ and $3.36 \%$ of fiber intake for adult women, $2.21 \%$ for men and $4.42 \%$ for the children. Keywords : noodle; composite; gluten; protein; fiber.
\end{abstract}

\begin{abstract}
ABSTRAK
Latar Belakang : Penyandang autism spectrum disorder (ASD) dan celiac disease tidak dapat menerima gluten yang masuk kedalam tubuh. Mi merupakan salah satu makanan pokok sumber karbohidrat yang terbuat dari gandum. Gandum memiliki kandungan gluten yang tinggi, sedangkan mi adalah makanan pokok terbanyak kedua setelah nasi. Salah satu alternatif bahan makanan sumber karbohidrat yang bebas gluten adalah singkong. Olahan singkong yaitu mocaf dan tepung tapioka memiliki sifat fisik yang menyerupai tepung terigu sehingga diharapkan dapat menggantikan tepung terigu dalam pembuatan mi. Singkong memiliki kadar protein yang rendah, oleh karena itu dilakukan penelitian mengenai penambahan jumlah telur terhadap kadar protein mi basah bebas gluten agar sesuai dengan standar nasional indonesia (SNI) yaitu 8\%, serat, tingkat kekenyalan dan penerimaan mi basah bebas gluten berbahan baku tepung komposit ( tepung mocaf, tapioka dan maizena).

Tujuan : Menganalisis pengaruh penambahan telur terhadap kadar protein, serat, tingkat kekenyalan dan penerimaan mi basah bebas gluten berbahan baku tepung komposit.

Metode : Merupakan penelitian eksperimental dengan rancangan acak lengkap, dengan 4 perlakuan menggunakan 1 kontrol dan 3 variasi penambahan jumlah telur (5 butir telur, 6 butir telur, 7 butir telur). Analisis laboratorium yang dilakukan adalah uji kadar protein, serat dan tingkat kekenyalan. Uji tingkat penerimaan dilakukan dengan uji hedonik pada 20 orang panelis agak terlatih. Analisis statistik kadar protein, kadar serat dan tingkat kekenyalan diuji menggunakan uji ANOVA One Way CI 95\% dengan uji lanjut LSD (Least Significance Different). Analisis statistik untuk tingkat penerimaan menggunakan uji Friedman CI 95\% dengan uji lanjut Wilcoxon.

Hasil : Penambahan jumlah telur mempengaruhi kadar protein, serat dan tingkat kekenyalan mi basah bebas gluten. Penambahan jumlah telur juga mempengaruhi tingkat penerimaan dari segi warna dan tekstur tetapi tidak
\end{abstract}

${ }^{*}$ Penulis Penanggungjawab 
mempengaruhi aroma dan rasa. Hasil penilaian terbaik didapat pada mi basah bebas gluten berbahan baku tepung komposit dengan 5 butir telur dengan kadar protein 7,66\%, serat 0,84\% dan tingkat kekenyalan 41,83 mm/g/detik. Simpulan : Mi basah bebas gluten berbahan baku tepung komposit dengan 5 butir telur merupakan mi terbaik dan dapat diterima oleh panelis. Mi basah tersebut menyumbang asupan serat sebesar 3,36\% untuk wanita dewasa, 2,21\% untuk pria dewasa dan 4,42\% untuk anak-anak.

Kata Kunci : mie; komposit; gluten; protein; serat.

\section{PENDAHULUAN}

Penyandang celiac disease yang mengkonsumsi gluten akan mengalami reaksi imun yang berlebih dan merusak dinding usus halus penderita tersebut. ${ }^{1}$ Penelitian di amerika memperkirakan 1 dari 133 orang sehat menyandang penyakit celiac disease tetapi $97 \%$ penderita tidak terdiagnosa. Kasus yang ditemukan dalam penelitian menyatakan bahwa $60 \%$ anakanak dan $41 \%$ orang dewasa merupakan penyandang celiac disease tanpa gejala. $^{2}$ Prevalensi Autism Spectrum Disorder (ASD) memiliki kecenderungan meningkat setiap tahunnya. Data penyandang ASD di amerika tahun 2006 berjumlah 9 dari 1000 anak usia 8 tahun menderita ASD, sedangkan pada tahun 2008 jumlahnya meningkat menjadi 11 dari 100 anak usia 8 tahun menderita ASD. Kejadian ASD lebih sering pada laki-laki dibandingkan perempuan dimana laki-laki ditemukan 1 kasus dari 54 orang dan perempuan ditemukan 1 kasus dari 252 orang. ${ }^{3}$ Penyandang ASD disarankan untuk menjalani diet gluten-free, casein-free (GFCF) karena penyandang ASD tidak dapat mencerna gluten dan kasein dengan baik. ${ }^{1}$ Gluten yang tidak tercerna dan terbawa ke otak akan ditangkap oleh reseptor opioid dan dianggap sebagai morfin, hal ini menyebabkan timbulnya sikap tempramental dari penyandang ASD. Diet GFCF tersebut membuat penyandang ASD rentan kekurangan asupan kalori, kalsium, serat, dan vitamin (A, D, B kompleks) karena sebagian besar bahan makanan sumber kalori, kalsium, serat dan vitamin mengandung gluten dan kasein. ${ }^{4}$

Data SUSENAS (survey sosial ekonomi nasional) tahun 2008 hingga 2012 menunjukkan adanya ketidakseimbangan pola makan rakyat Indonesia dimana padi-padian menjadi jenis makanan dominan yang dikonsumsi oleh masyarakat Indonesia dibandingkan dengan sumber karbohidrat yang lain. Data SUSENAS juga menunjukkan adanya kecenderungan konsumsi umbi-umbian yang menurun dari tahun 2008 hingga 2012. ${ }^{5}$ Jumlah konsumsi padi-padian yang lebih dominan dan konsumsi umbi-umbian yang cenderung berkurang bertentangan dengan salah satu target pencapaian dari Kementrian
Pertanian yaitu meningkatkan diversifikasi pangan. ${ }^{6}$ Data survey APTINDO tahun 2010 menunjukkan bahwa dari golongan padi-padian yang paling banyak dikonsumsi adalah beras dan gandum. Beras dikonsumsi sebagian besar dalam bentuk nasi sedangkan gandum sebagian besar dikonsumsi dalam bentuk mi. ${ }^{7}$

Mi dapat menjadi alternatif makanan pokok pengganti nasi karena memiliki kandungan karbohidrat yang tinggi. Mi merupakan makanan pokok terbanyak kedua yang dikonsumsi oleh masyarakat Indonesia setelah nasi. Mi lebih mudah diolah, praktis dan memiliki banyak variasi menu masakan terutama variasi rasa mi instan yang beragam. ${ }^{8}$

Gluten merupakan protein yang terdapat pada beberapa bahan makanan golongan serealia. Bahan makanan golongan serealia yang paling banyak mengandung gluten adalah gandum / tepung terigu. Tepung terigu mengandung gluten sebanyak $80 \%$ dari total protein yang terkandung dalam terigu. ${ }^{9}$ Gluten membentuk tekstur mi menjadi kenyal dan mengembang. Semakin tinggi kadar gluten maka semakin baik tekstur mi yang dihasilkan tetapi tidak semua orang dapat mengkonsumsi dan mencerna gluten dengan baik. Individu yang memiliki alergi terhadap gluten, penyandang celiac disease dan penyandang autism spectrum disorder (ASD) harus menghindari gluten agar tidak timbul dampak buruk pada tubuh. ${ }^{1,10}$

Umbi-umbian merupakan salah satu alternatif yang dapat digunakan sebagai makanan pokok yang bebas gluten. Umbi-umbian merupakan bahan pangan lokal yang mudah didapatkan tanpa harus mengimport dari luar negeri dan tersedia sepanjang tahun. Hal tersebut membuat umbi-umbian dapat menjadi alternatif bahan pangan pokok yang menguntungkan. Salah satu umbi yang tinggi kalori dan dapat digunakan sebagai makanan pokok alternatif bebas gluten adalah singkong. Tepung mocaf (modified cassava flour) adalah tepung yang terbuat dari singkong yang mengalami proses fermentasi terlebih dahulu sehingga didapatkan tepung yang memiliki sifat fisik (daya kembang) setara dengan tepung terigu tipe II (tepung terigu protein sedang). Tepung 
mocaf yang terbuat dari singkong juga memiliki kandungan kalsium lebih tinggi dibandingkan dengan tepung terigu dan lebih mudah dicerna. Tepung mocaf memiliki sifat fisik yang paling mendekati tepung terigu sehingga dapat digunakan untuk membuat mi bebas gluten. ${ }^{11}$ Tepung mocaf tidak $100 \%$ identik dengan tepung terigu oleh karena itu diperlukan tambahan tepung tapioka dan maizena untuk mendapatkan tekstur mi yang baik. Kandungan serat pada tepung mocaf $(12 \%$ lebih tinggi dari tepung terigu) ${ }^{11}$ membuat adonan mi menjadi lebih rapuh dan kurang liat. Kandungan serat yang cukup tinggi tersebut diharapkan mampu meningkatkan kandungan serat produk mi basah. Tepung tapioka memiliki karakteristik mengentalkan dan berfungsi sebagai pengikat dalam adonan sedangkan tepung maizena memiliki karakteristik melembutkan adonan, ${ }^{12}$ selain itu tepung tapioka dan tepung maizena memiliki karakteristik fisikokimia yang mendekati tepung terigu yaitu ukuran granul, kadar amilosa, amilopektin dan suhu gelasi. Penambahan tepung tapioka dan tepung maizena diharapkan dapat membentuk tekstur mi bebas gluten yang baik.

Mi bebas gluten dapat menjadi solusi yang aman dikonsumsi bagi setiap individu terutama bagi penyandang ASD. Penggantian tepung terigu berpengaruh terhadap kadar protein produk mi basah, karena tepung mocaf memiliki kadar protein yang lebih rendah $(0,83 \%)$. Produk mi yang dihasilkan diharapkan dapat memenuhi kadar protein minimal sesuai dengan Standar Nasional Indonesia (SNI) yaitu protein minimal $8 \%$ dengan memberikan perlakuan penambahan jumlah telur.

\section{METODE}

Penelitian yang dilakukan merupakan penelitian dalam bidang food producing. Penelitian dilakukan di Laboratorium Ilmu Gizi dan Teknologi Pangan Universitas Muhammadiyah Semarang pada bulan Juni hingga Juli 2013.

Penelitian ini merupakan penelitian eksperimental dengan rancangan acak lengkap menggunakan 3 variasi jumlah telur dan 1 kontrol $(\mathrm{t}=4)$ dengan simbol : $\mathrm{n}_{0}=$ kontrol, $\mathrm{n}_{1}=5$ butir telur, $\mathrm{n}_{2}=6$ butir telur, $\mathrm{n}_{3}=7$ butir telur dan dilakukan pengulangan sebanyak tiga kali untuk setiap perlakuan. Kontrol dalam perlakuan ini adalah mi basah yang terbuat dari tepung terigu dan telur sesuai dengan standar resep mi basah yang digunakan dalam penelitian ini. Kelompok perlakuan adalah mi basah bebas gluten yang terbuat dari tepung komposit (tepung mocaf, tapioka dan maizena) yang sama namun menggunakan jumlah telur yang berbeda dalam tiap perlakuan.

Bahan utama yang digunakan dalam pembuatan mi basah bebas gluten adalah tepung mocaf dari produsen "Sari Tany", tepung tapioka "Gunung Agung" dan tepung maizena "Maizenaku" dan untuk kontrol digunakan tepung terigu "Cakra Kembar". Bahan lain yang dibutuhkan adalah telur, garam, minyak kelapa dan air.

Tahap awal pembuatan mi basah bebas gluten adalah menimbang bahan sesuai dengan takaran, kemudian campuran tepung dan garam diaduk rata. Telur dikocok lepas dan masukkan kedalam tepung, minyak kelapa dan air ditambahkan sdan adonan diuleni hingga kalis. Adonan kemudian digiling dengan ketebalan $1 \mathrm{~mm}$ dan dipotong menggunakan pasta maker dengan pemotong ukuran besar. Adonan yang telah berbentuk mi kemudian direbus dalam air mendidih selama 3 menit.

Data yang dikumpulkan adalah kadar protein, kadar serat, tingkat kekenyalan dan tingkat penerimaan. Kadar protein diukur menggunakan metode Mikro-Kjeldahl ${ }^{13}$, kadar serat diukur menggunakan metode gravimetri ${ }^{13}$ dan tingkat kekenyalan diukur menggunakan alat penetrometer/texture analyzer yang dilakukan di Laboratorium Ilmu Gizi dan Teknologi Pangan Universitas Muhammadiyah Semarang. Penilaian tingkat penerimaan menggunakan uji hedonik ${ }^{14}$ yang meliputi aspek warna, aroma, rasa dan tekstur dari produk mi bebas gluten. Uji hedonik dilakukan kepada 20 orang panelis agak terlatih yaitu mahasiswa Program Studi Ilmu Gizi Universitas Diponegoro dengan 5 skala penilaian yaitu $1=$ sangat tidak suka, $2=$ tidak suka, $3=$ netral, $4=$ suka, $5=$ sangat suka.

Pengaruh penambahan jumlah telur terhadap kadar protein, kadar serat dan tingkat kekenyalan diuji menggunakan uji statistik Analysis of Varians (ANOVA)-one way data distribusi normal dengan derajat kepercayaan masing-masing 95\% dan dilanjutkan dengan uji lanjut posthoc LSD. Data tingkat penerimaan berdistribusi tidak normal maka diuji menggunakan uji statistik Friedman dengan derajat kepercayaan 95\%, kemudian dilanjutkan dengan posthoc uji Wilcoxon untuk mengetahui beda nyata antar perlakuan. 


\section{HASIL}

\section{Kadar Protein}

Data kadar protein mi basah bebas gluten dapat dilihat secara lengkap pada Lampiran 6, sedangkan hasil analisis statistik dapat dilihat pada Lampiran 7 dan Tabel 1. Kadar protein mi memiliki rerata 6,23-9,53 g/100g. Mi basah perlakuan 3 (7 butir telur) memiliki kadar protein tertinggi, sedangkan mi basah kontrol memiliki kadar protein terendah. Hasil uji statistik menyatakan bahwa terdapat pengaruh penambahan jumlah telur terhadap kadar protein mi basah bebas gluten. Hal tersebut berarti semakin banyak jumlah telur yang digunakan maka semakin tinggi kadar protein mi basah.

Tabel 1. Hasil Analisis Kadar Protein Mi Basah Bebas Gluten

\begin{tabular}{cc}
\hline Perlakuan & Kadar Protein $(\mathrm{g} / 100 \mathrm{~g})$ \\
\hline $\mathrm{n}_{0}$ (kontrol) & $6,23 \pm 0,15^{\mathrm{a}}$ \\
$\mathrm{n}_{1}(5$ butir telur $)$ & $7,66 \pm 0,25^{\mathrm{b}}$ \\
$\mathrm{n}_{2}(6$ butir telur) & $7,92 \pm 0,07^{\mathrm{b}}$ \\
$\mathrm{n}_{3}(7$ butir telur $)$ & $9,53 \pm 0,06^{\mathrm{c}}$ \\
\hline & $\mathrm{p}=0,000$ \\
\hline
\end{tabular}

Uji one way anova. Uji post-hoc LSD; $\mathrm{n}_{0}$ memiliki perbedaan bermakna dengan seluruh perakuan $\mathrm{n}_{1}$, $\mathrm{n}_{2}, \mathrm{n}_{3} ; \mathrm{n}_{3}$ memiliki perbedaan bermakna dengan perlakuan $\mathrm{n}_{1}$ dan $\mathrm{n}_{2}$

\section{Kadar Serat}

Data kadar serat mi basah bebas gluten dapat dilihat secara lengkap pada Lampiran 8. Hasil analisis statistik data tersebut dapat dilihat pada Lampiran 9 dan Tabel 2.

Kadar serat mi basah bebas gluten memiliki rerata $0,62-1,47 \mathrm{~g} / 100 \mathrm{~g}$ dimana mi basah perlakuan 3 (7 butir telur) memiliki kadar serat paling tinggi dan mi basah kontrol memiliki kadar serat terendah. Hasil uji statistik menyatakan bahwa terdapat pengaruh penambahan jumlah telur terhadap kadar serat mi basah bebas gluten. Hasil analisis tersebut menyatakan bahwa semakin banyak telur yang digunakan maka kadar serat semakin tinggi.

Tabel 2. Hasil Analisis Kadar Serat Mi Basah Bebas Gluten

\begin{tabular}{cc}
\hline Perlakuan & Kadar Serat $(\mathrm{g} / 100 \mathrm{~g})$ \\
\hline $\mathrm{n}_{0}$ (kontrol) & $0,62 \pm 0,04^{\mathrm{a}}$ \\
$\mathrm{n}_{1}(5$ butir telur $)$ & $0,84 \pm 0,09^{\mathrm{b}}$ \\
$\mathrm{n}_{2}(6$ butir telur) & $0,99 \pm 0,13^{\mathrm{b}}$ \\
$\mathrm{n}_{3}(7$ butir telur $)$ & $1,47 \pm 0,07^{\mathrm{c}}$ \\
\hline & $\mathrm{p}=0,000$ \\
\hline
\end{tabular}

Uji one way anova. Uji post-hoc LSD; $\mathrm{n}_{0}$ memiliki perbedaan bermakna dengan seluruh perakuan $\mathrm{n}_{1}$, $\mathrm{n}_{2}, \mathrm{n}_{3} ; \mathrm{n}_{3}$ memiliki perbedaan bermakna dengan perlakuan $\mathrm{n}_{1}$ dan $\mathrm{n}_{2}$.

\section{Tingkat Kekenyalan}

Data tingkat kekenyalan mi basah bebas gluten dapat dilihat secara lengkap pada Lampiran 10. Hasil analisis statistik data tersebut dapat dilihat pada Lampiran 11 dan Tabel 3. Nilai yang kecil menunjukkan kekenyalan yang tinggi, semakin kecil nilai maka semakin kenyal tekstur mi tersebut.

Tingkat kekenyalan mi basah bebas gluten memiliki rerata 29,30-74,30 $\mathrm{mm} / \mathrm{g} /$ detik dimana mi basah kontrol merupakan mi yang paling kenyal dan mi basah perlakuan 3 (7 butir telur) memiliki kekenyalan yang paling rendah. Hasil uji statistik menyatakan bahwa terdapat pengaruh penambahan jumlah telur terhadap tingkat kekenyalan mi basah bebas gluten. Semakin banyak jumlah telur maka semakin rendah kekenyalan mi basah. 
Tabel 3. Hasil Analisis Tingkat Kekenyalan Mi Basah Bebas Gluten

\begin{tabular}{cc}
\hline Perlakuan & Tingkat Kekenyalan $(\mathrm{mm} / \mathrm{g} /$ detik $)$ \\
\hline $\mathrm{n}_{0}$ (kontrol) & $29,30 \pm 3,07^{\mathrm{a}}$ \\
$\mathrm{n}_{1}(5$ butir telur $)$ & $41,83 \pm 2,92^{\mathrm{b}}$ \\
$\mathrm{n}_{2}(6$ butir telur $)$ & $60,65 \pm 2,15^{\mathrm{c}}$ \\
$\mathrm{n}_{3}(7$ butir telur $)$ & $74,30 \pm 1,21^{\mathrm{d}}$ \\
\hline & $\mathrm{p}=0,000$
\end{tabular}

Uji one way anova. Uji post-hoc LSD; $\mathrm{n}_{0}$ memiliki perbedaan bermakna dengan seluruh perakuan $\mathrm{n}_{1}, \mathrm{n}_{2}, \mathrm{n}_{3}$

\section{Tingkat Penerimaan}

Rangkuman hasil uji hedonik dapat dilihat pada Lampiran 12 dan analisis statistik data pada Lampiran 14 dan Tabel 4.

Tabel 4. Hasil Analisis Tingkat Penerimaan Mi Basah Bebas Gluten.

\begin{tabular}{|c|c|c|c|c|c|c|c|c|}
\hline \multirow{2}{*}{ Perlakuan } & \multicolumn{2}{|c|}{ Warna } & \multicolumn{2}{|c|}{ Aroma } & \multicolumn{2}{|c|}{ Rasa } & \multicolumn{2}{|c|}{ Tekstur } \\
\hline & Rerata & Ket & Rerata & Ket & Rerata & Ket & Rerata & Ket \\
\hline $\mathrm{n}_{0}$ (kontrol) & $4,60 \pm 0,60^{\mathrm{a}}$ & $\begin{array}{c}\text { Sangat } \\
\text { suka }\end{array}$ & $3,40 \pm 0,88$ & Netral & $3,15 \pm 0,88^{\mathrm{ab}}$ & Netral & $2,75 \pm 0,91 \mathrm{a}$ & Netral \\
\hline $\begin{array}{l}\mathrm{n}_{1} \text { (5 butir } \\
\text { telur) }\end{array}$ & $2,60 \pm 0,94^{b}$ & Netral & $3,40 \pm 0,88$ & Netral & $3,35 \pm 0,88^{b}$ & Netral & $3,55 \pm 0,76 b c$ & Suka \\
\hline $\begin{array}{c}\mathrm{n}_{2}(6 \text { butir } \\
\text { telur })\end{array}$ & $2,60 \pm 0,88^{b}$ & Netral & $3,20 \pm 1,06$ & Netral & $2,70 \pm 1,13^{\mathrm{a}}$ & Netral & $2,85 \pm 0,93 a$ & Netral \\
\hline $\begin{array}{c}\mathrm{n}_{3}(7 \mathrm{~b} \text { utir } \\
\text { telur })\end{array}$ & $2,60 \pm 0,94^{b}$ & Netral & $3,15 \pm 1,04$ & Netral & $2,90 \pm 0,91^{\mathrm{ab}}$ & Netral & $3,20 \pm 0,83 \mathrm{ac}$ & Netral \\
\hline & $\mathrm{p}=0$ & & $p=0$ & & $\mathrm{p}=0,0$ & & $\mathrm{p}=0,0$ & \\
\hline
\end{tabular}

Uji Friedman. Uji lanjut Wilcoxon ( $\alpha: 0,05)$ : Huruf yang berbeda pada kolom yang sama menunjukkan adanya perbedaan yang nyata.

Hasil uji tingkat penerimaan dari parameter warna menujukan bahwa ada pengaruh penambahan jumlah telur terhadap tingkat penerimaan warna mi basah bebas gluten berbahan baku tepung komposit dengan nilai $\mathrm{p}=0.000$. kelompok kontrol memiliki warna yang paling disukai oleh panelis sedangkan kelompok perlakuan 1, 2 dan 3 memiliki derajat kesukaan yang sama yaitu masuk dalam katagori netral. Hasil uji tingkat penerimaan dari parameter aroma menunjukkan bahwa tidak ada pengaruh penambahan jumlah telur terhadap tingkat penerimaan aroma dan rasa mi basah bebas gluten berbahan baku tepung komposit. Hasil uji tingkat penerimaan dari parameter tekstur menunjukkan bahwa ada pengaruh penambahan jumlah telur terhadap tekstur mi basah bebas gluten berbahan baku tepung komposit dengan nilai $p=0,036$. Skor tertinggi yaitu pada kelompok perlakuan 1 (5 butir telur) yang masuk dalam kategori suka dan skor terendah yaitu kelompok kontrol bersama dengan perlakuan lain termasuk dalam katagori netral.

\section{PEMBAHASAN}

\section{Kadar Protein}

Mi merupakan salah satu alternatif bahan makanan pokok yang memiliki jumlah konsumsi terbanyak kedua di Indonesia setelah beras/nasi. Mi pada umumnya terbuat dari tepung terigu protein tinggi, dalam penelitian ini dibuat mi basah bebas gluten yang mengganti bahan baku tepung terigu dengan tepung komposit (tepung mocaf, tepung tapioka, tepung maizena). Penggantian tepung akan berpengaruh terhadar kadar protein mi basah yang menurut Standar Nasional Indonesia (SNI) minimal kandungan protein pada mi basah adalah $8 \% .^{15}$

Data yang didapatkan dalam penelitian ini menyatakan bahwa mi pelakuan 1 (5 butir telur) dan perlakuan 2 (6 butir telur) dapat mendekati SNI kadar protein mi basah serta 3 (7 butir telur) dapat memenuhi SNI protein mi basah. Kadar protein tertinggi adalah pada kelompok perlakuan 3 karena pada adonan mi kelompok tersebut menggunakan telur dalam jumlah yang paling banyak yaitu 7 butir telur. Telur merupakan salah satu sumber protein 
dengan bioavailabilitas tinggi dimana 90,9\% protein telur dapat dicerna di ileum manusia. ${ }^{16}$ Penelitian ini menggunakan telur ayam yang memiliki kandungan protein sebanyak 9 $\mathrm{g} / 100 \mathrm{~g}(9 \%) .{ }^{17}$ Kandungan protein pada telur ayam dapat membantu meningkatkan kadar protein produk mi bebas gluten dimana protein tepung komposit yang digunakan hanya $0,83 \%$ dari tepung mocaf, $1,2 \%$ dari tepung tapioka dan $0,3 \%$ dari tepung maizena. Kadar protein terendah adalah pada kelompok kontrol yaitu $6,23 \%$, meskipun pada standar resep mi basah kontrol menggunakan bahan tepung terigu protein tinggi dan 2 butir telur namun kadar protein tersebut tidak memenuhi SNI untuk mi basah. Hampir seluruh kelompok perlakuan dalam penelitian ini dapat memenuhi kadar protein minimal SNI kecuali kelompok kontrol sehingga terbukti penambahan jumlah telur dapat meningkatkan kadar protein mi basah bebas gluten.

Angka kecukupan gizi (AKG) protein adalah $50 \mathrm{~g} / \mathrm{hari}$, sedangkan konsumsi mi basah bebas gluten perlakuan 3 dapat mencukupi kebutuhan protein sebesar $19,06 \%$.

\section{Kadar Serat}

Kadar serat tertinggi adalah kelompok perlakuan 3 sebesar 1,47 g/100g. Kandungan serat dalam mi basah bebas gluten bersal dari tepung mocaf. Kandungan serat dalam tepung mocaf termasuk dalam golongan serat tidak larut air. Serat tidak dapat dicerna oleh tubuh, tetapi memiliki fungsi yang baik dalam saluran pencernaan seperti mencegah terjadinya konstipasi, meningkatkan volume feses sehingga cepat dikeluarkan dari saluran pencernaan. serat juga menghambat penyerapan kolesterol, lemak dan penyerapan kembali asam empedu. ${ }^{18}$

Hasil uji statistik menunjukkan bahwa mi basah bebas gluten dengan telur semakin banyak memiliki kadar serat yang semakin tinggi pula.

Hasil uji post-hoc LSD menunjukkan bahwa kontrol memiliki perbedaan yang berarti dengan seluruh perlakuan mi basah bebas gluten, mi perlakuan 1 dan 2 memiliki perbedaan bermakna dengan mi basah perlakuan 3. Mengkonsumsi mi basah bebas gluten perlakuan 3 berkontribusi terhadap konsumsi serat per hari sebesar 7,73\% untuk anak-anak, $3,87 \%$ untuk pria dewasa dan $5,88 \%$ untuk wanita dewasa.
Penelitian ini menggunakan kelompok kontrol yaitu mi basah yang terbuat dari tepung terigu dan 2 butir telur, sedangkan kelompok perlakuan 1,2 dan 3 menggunakan bahan baku tepung komposit yang menggunakan jumlah telur yang bebeda yaitu 5, 6 dan 7 telur. Bahan baku dalam pembuatan mi basah bebas gluten yang mengandung serat adalah tepung mocaf dan tepung tapioka. Dalam penelitian ini hanya meneliti serat kasar saja dimana kandungan serat kasar tepung mocaf adalah $0,83 \%$ sedangkan menurut teori serat pangan yang dimiliki oleh tepung mocaf berkisar antara 3,99-6,66\% dan serat pangan tepung tapioka sebesar $0,9 \% .{ }^{19}$

Secara teori tidak terbukti bahwa telur memiliki kandungan serat tetapi kadar serat mi basah bebas gluten berbanding lurus dengan jumlah telur yang digunakan. Peningkatan kadar serat yang berbanding lurus dengan jumlah telur yang digunakan dapat terjadi akibat proses pengolahan dimana penambahan air pada pembuatan mi basah tiap kelompok perlakuan berbeda. Kelompok perlakuan mi basah bebas gluten dengan lebih sedikit telur membutuhkan jumlah tambahan air yang lebih banyak untuk membuat adonan dapat kalis untuk diuleni. Kelompok perlakuan dengan telur lebih banyak tidak membutuhkan tambahan air yang banyak untuk dapat diuleni hingga dapat kalis. Perbedaan tambahan air yang dibutuhkan membuat berat kering dari tiap kelompok perlakuan berbeda, dalam penelitian ini kadar serat mi basah diukur dalam keadaan sampel matang sehingga berat kering tiap sampel berbeda. Hal tersebut membuat hasil dari kadar serat meningkat meskipun takaran tepung sumber serat pada tiap kelompok perlakuan sama.

Mi basah dengan tepung komposit terbukti memberikan kontribusi asupan serat kasar yang lebih tinggi dibandingkan dengan tepung terigu. Selain serat kasar, tepung komposit memiliki serat larut yang cukup tinggi, sehingga diperkirakan kandungan serat pangan mi basah bebas gluten akan jauh lebih tinggi dari mi berbahan baku tepung terigu.

\section{Tingkat Kekenyalan}

Tingkat kekenyalan yang tertinggi adalah kelompok kontrol berbahan baku terigu, sedangkan dari kelompok perlakuan saja tingkat kekenyalan tertinggi adalah kelompok perlakuan 1. Tingkat kekenyalan mi basah 
bebas gluten dipengaruhi oleh jenis tepung yang digunakan, setiap tepung mempunyai karakteristik yang berbeda seperti pada bentuk granula, kadar amilosa dan amilopektin serta suhu gelasi yang membedakan kemampuan gelasi satu tepung dengan tepung yang lain. Tepung terigu memiliki granula berbentuk oval yang berukuran 2-35 mikron, kadar amilosa $25 \%$, amilopektin $75 \%$ dan suhu gelasi $52-64^{\circ} \mathrm{C}$. Tepung mocaf memiliki granula berbentuk oval berukuran 5-35 mikron, kadar amilosa 21,04-29,2\%, kadar amilopektin 79,6-78,8\% dan suhu gelasi 52$64^{\circ} \mathrm{C}$. Tepung tapioka memiliki granula berbentuk oval, berukuran 5-35 mikron, kadar amilosa 17\%, kadar amilopektin 83\% dan suhu gelasi $52-64^{\circ} \mathrm{C}$. Tepung maizena memiliki bentuk granula oval yang berukuran 6-30 mikron, kadar amilosa 24-26\%, kadar amilopektin $74-76 \%$ dan suhu gelasi 52$65^{\circ} \mathrm{C}^{53}$

Tepung komposit yang digunakan memiliki kadar amilosa, amilopektin dan suhu gelasi yang menyerupai tepung terigu, tetapi tepung komposit bebas gluten tidak memiliki protein gluten yang memberi sifat kenyal sehingga mi dengan bahan baku tepung komposit tidak dapat menyamai kekenyalan mi berbahan tepung terigu.

Hasil uji statistik menyatakan bahwa ada pengaruh penambahan jumlah telur terhadap tingkat kekenyalan mi basah bebas gluten. Jumlah telur berbanding terbalik dengan kekenyalan mi basah bebas gluten. Telur memiliki kandungan lemak yang menyebabkan adonan menjadi lebih lembut, semakin banyak telur yang digunakan semakin lembut mi yang dihasilkan. Hal tersebut berhubungan dengan sifat fisiologis telur yaitu daya emulsi dan daya kontrol kristalisasi. Daya emulsi adalah kemampuan untuk menyatukan dua jenis cairan yang secara normal tidak dapat bercampur sepeti minyak dengan air, kuning telur memiliki daya emulsi sehingga adanya kuning telur dapat menyebabkan penyerapan air yang lebih banyak. Selain itu putih telur memiliki daya kontrol kristalisasi dimana albumin dalam putih telur mencegah penguapan air sehingga adanya putih telur dalam adonan akan membuat adonan menjadi lebih lembut dan terasa lebih lembab. Kedua sifat tersebut dapat menyebabkan semakin banyak telur yang digunakan maka akan semakin lembut mi basah bebas gluten yang dihasilkan.

\section{Tingkat Penerimaan}

\section{a. Warna}

Hasil uji statistik yang dilakukan terhadap parameter warna mi bebas gluten menunjukkan adanya perbedaan yang bermakna. Mi basah bebas gluten memiliki warna yang lebih gelap dibandingkan dengan mi berbahan baku tepung terigu. Hal ini timbul karena warna dasar tepug mocaf yang terbuat dari singkong. Tepung mocaf sudah melalui proses fermentasi oleh bakteri asam laktat sehingga aroma khas dan warna coklat singkong berkurang $70 \%$ namun tidak hilang seluruhnya. Proses fermentasi mampu mengurangi jumlah nitrogen namun tidak seluruhnya hilang sehingga masih timbul warna coklat hasil akhir polimerisasi asam amino yang disebut dengan melanoidin. Melanoidin terbentuk akibat adanya reaksi pencoklatan non-enzimatis yang disebut reaksi maillard. Reaksi maillard dapat terjadi akibat suhu tinggi. Reaksi maillard berlangsung akibat adanya gula pereduksi bereaksi dengan asam amino primer yang terpolimerisasi yang membentuk senyawa berwarna coklat yang disebut melanoidin.

b. Aroma

Hasil uji statistik terhadap parameter aroma menunjukkan bahwa tidak ada perbedaan aroma seluruh perlakuan mi basah bebas gluten dengan kontrol. Aroma khas singkong dapat dikurangi dengan proses fermentasi yang dilakukan dalam pembuatan tepung mocaf sehingga pada penilaian skor uji hedonik masing-masing kelompok perlakuan tidak jauh berbeda.

c. Rasa

Rasa seluruh kelompok perlakuan mi basaah memiliki skor penilaian rasa yang tidak jauh berbeda dengan kontrol, semua termasuk dalam katagori netral. Hasil uji statistik menyatakan tidak ada perbedaan rasa antar kelompok sampel. Rasa mi basah bebas gluten tidak jauh berbeda dengan kontrol karena bahan baku yang digunakan memiliki rasa yang netral.

d. Tekstur

Hasil uji statistik terhadap parameter tekstur menunjukkan adanya perbedaan yang berarti antar kelompok perlakuan. Skor penilaian tekstur sampel mi basah tidak jauh berbeda namun tekstur kelompok perlakuan 1 
lebih disukai dibandingkan dengan kelompok perlakuan lain. Semakin banyak jumlah telur yang digunakan, maka mi yang dihasilkan akan semakin lembut sehingga tidak disukai oleh panelis.

\section{SIMPULAN}

1. Ada pengaruh penambahan jumlah telur terhadap kadar protein mi basah bebas gluten berbahan baku tepung komposit. Mi basah bebas gluten perlakuan 1 dan 2 memiliki kadar protein yang mendekati SNI $(8 \%)$ yaitu $7,66 \%$ untuk perlakuan 1 dan $7,92 \%$ untuk perlakuan 2. Mi basah perlakuan 3 (7 butir telur) memiliki kadar protein paling tinggi yaitu $9,53 \mathrm{~g} / 100 \mathrm{~g}$.

2. Ada pengaruh penambahan telur terhadap kadar serat mi basah bebas gluten berbahan baku tepung komposit. Mi basah perlakuan 3 ( butir telur) memiliki kadar serat paling tinggi yaitu $1,47 \mathrm{~g} / 100 \mathrm{~g}$.

3. Ada pengaruh penambahan telur terhadap tingkat kekenyalan dari seluruh perlakuan mi basah bebas gluten berbahan baku tepung komposit. Mi kontrol memiliki kekenyalan yang paling tinggi, tetapi tekstur yang paling disukai oleh panelis adalah mi perlakuan 1 (5 butir telur).

4. Semua kelompok perlakuan memiliki tingkat kesukaan panelis yang sama yaitu termasuk dalam katagori netral kecuali warna pada kelompok kontrol (sangat suka) dan tekstur pada kelompok perlakuan 1(suka).

\section{DAFTAR PUSTAKA}

1. Mulloy, A, et al. Gluten-free and casein-free diets in the treatment of autism spectrum disorders: A systematic review. Research in Autism Spectrum Disorders (2009), doi:10.1016/j.rasd.2009.10.008

2. Celiac disease center.Celiac Disease Facts and Figures. University of chicago.2005.

3. Center for Disease Control and Prevention.Prevalence of Autism Spectrum Disorders-Autism and Developmental Disabilities Moniyoring Network,14 Sites,United States,2008.Morbidity and Monitoring Weekly Report, US Department of Health and Human Service.2012.

4. Mashabi, N.A dkk. Hubungan Antara Pengetahuan Gizi Ibu dengan Pola Makan Anak Autis.Makara Kesehatan vol.13.2009.84-86.

5. Survey Sosial Ekonomi Nasional (SUSENAS). Modul Konsumsi.Badan Pusat Statistik (BPS).2008, 2009, 2010, 2011, 2012.
6. Ariani, Mewa. Diversifikasi konsumsi Pangan di Indonesia. Pusat Analisa Sosial Ekonomi dan Kebijakan Pertanian Bogor.2010.

7. NN. Pertumbuhan Indonesia Tahun 2012-2030 dan Overview Industri Tepung Terigu Nasional Tahun 2012. Asosiasi Produsen Tepung Terigu Indonesia (APTINDO).2012.

8. Arianto, N.T. Pola Makan Mie Instan : Studi Antropologi Gizi pada Mahasiswa Antropologi FISIP UNAIR. Departemen Antropologi FISIP Universitas Airlangga.Surabaya.2011.

9. NN.Gluten-Free, Casein-Free Diet for Autism Spectrum Disorder.Children's Hospitals and Clinics of Minesota.2010.

10. Rostami, Kamran dkk. Non-coeliac Gluten Sensitivity.BMJ.2012;345:e 7982.

11. Yeni, Dahlia S.P.Tepung Mocaf Alternatif Pengganti Terigu.Balai Pendidikan dan Pelatihan Daerah Provinsi Jawa Barat.2012.

12. Kusumaningrum, M.Pengaruh Berbagai Macam Filler terhadap Kadar Air, Rendemen dan Sifat Organoleptik (warna) Chicken Nugget. Animal Agriculture Journal vol.2.2013.hal 370-376.

13. Sudarmadji, Slamet, Bambang Haryono, Suhardi.Prosedur Analisa Untuk Bahan Makanan dan Pertanian.Fakultas Teknologi Pertanian, Universitas Gadjah Mada.Yogyakarta : Liberty Yogya.2007.

14. Rahayu, Winiati Pudji dkk. Analisis Mutu.Direktorat Surveilan dan Penyuluhan Keamanan Pangan Departemen Kesehatan Republik Indonesia.2003.

15. Badan Standardisasi Nasional.Standar Nasional Indonesia (SNI 01-2897-1992) tentang Mi Basah.Jakarta:Departemen Perindustrian dan Perdagangan Republik Indonesia,1992.

16. Evenepoel, pieter,Benny Geypens, Anja Luypaerts, Martin Hiele, Yvo Ghoos dan Paul Rutgeerts.Digestibility of cook and raw egg protein in humans as assessed by stable isotope techniques. Belgium : Department of medicine, division of gastroenterology and gastrointestinal research centre.University hospital leuven.1998.

17. United States Department of Agriculture.2007.

18. Mahan, L.K,Sylvia E.Krause's : Food, Nutrition and Diet Therapy.13 ${ }^{\text {th }}$ ed.USA:Elsevier.2012.

19. Niba, L.L, M.M. Bokanga, F.L.Jackson, D.S. Schlimme dan B.W.Li.Psycochemical properties and starch granular characteristic of granular form various Manihot esculenta (cassava) genotypes.Blacksburg : Department of Human Nutririon, Food and Exercise.Virginia polytechnic institute and state university.2002. 